\title{
DIGITALISASI AKSARA JAWA DAN PEMANFAATANNYA \\ SEBAGAI MEDIA PEMBELAJARAN BAGI MUSYAWARAH GURU \\ MATA PELAJARAN BAHASA JAWA SMP KABUPATEN KLATEN ${ }^{1}$
}

\author{
Eric Kunto Aribowo \\ Program Studi Pendidikan Bahasa dan Sastra Daerah \\ Fakultas Keguruan dan Ilmu Pendidikan \\ Universitas Widya Dharma \\ Jl. Ki Hajar Dewantara, Karanganom, Klaten Utara \\ E-mail: erickunto@unwidha.ac.id
}

\begin{abstract}
ABSTRAK
Kegiatan pengabdian kepada masyarakat ini memiliki tujuan agar guru-guru mata pelajaran Bahasa Jawa memiliki kecakapan dalam (1) melakukan pemasangan fon Hanacaraka di perangkat komputer; (2) mengetik aksara Jawa dengan terampil; (3) serta memproduksi materi-materi pembelajaran aksara Jawa yang personal, sesuai dengan kondisi dan kebutuhan anak didiknya masing-masing dalam bentuk flashcard, meme, comic strip, dan running text. Khalayak sasaran dari kegiatan ini adalah anggota dan pengurus MGMP Bahasa Jawa SMP yang terdiri dari 42 peserta yang berasal dari 32 sekolah se-Kabupaten Klaten. Kegiatan ini didahului dengan melakukan analisis kebutuhan melalui wawancara dan survei terhadap guru-guru bahasa Jawa. Focus group discussion melibatkan MGMP Bahasa Jawa untuk menentukan prioritas kendala-kendala yang jamak dihadapi para guru, yang akan dicari solusinya. Implementasi kegiatan dilakukan dengan cara demonstrasi, mempraktikkan pemasangan fon Hanacaraka, pengetikan aksara Jawa, dan pembuatan media-media pembelajaran menggunakan perangkat komputer. Bentuk aktivitas dirancang dengan menggunakan strategi pelatihan untuk menjamin keterampilan peserta dalam penulisan dan produksi media pembelajaran dengan aksara Jawa di perangkat komputer dapat dikuasai dengan baik. Hasil review dan evaluasi pelaksanaan kegiatan menunjukkan materi yang diajarkan tergolong mudah untuk dipraktikkan. Meningkatnya keterampilan guru dalam hal digitalisasi aksara Jawa dibuktikan dengan kemampuan dalam pembuatan media pembelajaran aksara Jawa menggunakan perangkat komputer. Pada dasarnya sebagian besar peserta sepakat bahwa materi yang diberikan memiliki potensi yang besar untuk diterapkan dalam proses belajar mengajar di sekolah masing-masing.
\end{abstract}

Kata kunci: pemberdayaan masyarakat, hanacaraka, media pembelajaran, teknologi pembelajaran, instructional design

\footnotetext{
${ }^{1}$ Aribowo, E. K. (2018). "Digitalisasi Aksara Jawa dan Pemanfaatannya sebagai Media Pembelajaran bagi Musyawarah Guru Mata Pelajaran Bahasa Jawa SMP Kabupaten Klaten”. Warta LPM, (21)1. hal. 59-70.
} 


\section{PENDAHULUAN}

Hasil survei melalui wawancara dan dan penyebaran angket kepada beberapa anggota MGMP Bahasa Jawa SMP didapati informasi bahwa kondisi mata pelajaran bahasa Jawa perlu mendapatkan perhatian yang lebih intensif, terutama imbas dari hadirnya Kurikulum 2013 yang tidak secara tersurat mencantumkan mata pelajaran Bahasa Jawa di jenjang pendidikan dasar dan menengah. Bahkan, jumlah jam pelajaran Bahasa Jawa hanya 2 JP per minggu (Gubernur Jawa Tengah, 2012, 2013). Konsekuensi dari kebijakan itu antara lain munculnya persepsi anak didik bahwa mata pelajaran Bahasa Jawa kurang diminati dan memiliki kesan kurang menarik.

Kendala-kendala utama yang dihadapi oleh guru-guru mata pelajaran Bahasa Jawa antara lain terkait langkanya media pembelajaran, kurangnya minat dan motivasi belajar anak didik, sarana dan infrastruktur yang kurang memadai, serta beban administratif guru. Semenjak bergulirnya Sertifikasi Guru, para guru makin disibukkan dengan tugas-tugas administrasi sebagai dampak sebagai "guru profesional". Fokus dan perhatian kepada anak didik semakin pudar, RPP jarang dimodifikasi, media pembelajaran dan alat peraga menjadi barang langka yang ditemui anak didik. Imbasnya, anak didik menjadi cepat jenuh dalam pembelajaran.

Dari penelusuran hasil-hasil PTK, tidak banyak dihasilkan model-model pembelajaran baru yang menjadi jawaban atau solusi masalah dalam pembelajaran bahasa Jawa. Sebagian besar guru masih berkutat pada model pembelajaran TPS, Jigsaw, STAD, Role Playing, bahkan ceramah. Belum banyak guru yang berani mengeksplorasi model-model pembelajaran lebih-lebih media pembelajaran baru dari hasil pengalamannya mengajar sekian tahun sehingga dapat dikatakan bahwa model pembelajaran yang diterapkan untuk mata pelajaran Bahasa Jawa kurang dinamis dan menjenuhkan (Aribowo, 2015a).

Fakta ini juga dimungkinkan karena status Bahasa Jawa sebagai mata pelajaran yang tidak diujikan dalam Ujian Akhir Nasional sehingga gairah untuk menciptakan pembelajaran yang bermakna menjadi kurang. Media pembelajaran juga menjadi penghambat lain karena para guru mengalami kesulitan ketika mencari media-media pembelajaran bahasa Jawa di pasaran (dibandingkan dengan bahasa Indonesia atau bahasa asing seperti bahasa Inggris atau bahasa Arab). Umumnya, hanya ditemukan poster, buku teks, dan LKS di toko-toko buku sekitar.

Media pembelajaran menjadi salah satu masalah pokok yang sering menjadi keluhan para guru, meskipun sebenarnya beberapa gagasan terkait pembuatan media pembelajaran beberapa kali telah diungkap (Kartikasari dan Nugroho, 2010; Aribowo, 2014a, 2014b, 2015b). Perihal media pembelajaran sebenarnya termasuk dalam salah satu tugas utama guru dalam rangka mendesain atau merancang sebuah pembelajaran yang bermakna bagi anak didik agar mereka termotivasi untuk menambah pengetahuan, kecakapan, dan karakter mereka.

Topik aksara Jawa dipilih karena merupakan problem atau kendala umum yang jamak ditemukan hampir di keseluruhan sekolah. Alasan lain adalah karena topik ini sebenarnya bisa diintegrasikan ke dalam materi-materi pelajaran Bahasa Jawa lainnya. Alasan pemilihan MGMP tingkat SMP karena secara psikologis anak didik pada tingkat menengah pertama mulai menyukai tindakan-tindakan eksperimen dan ekplorasi sehingga lebih cepat merasa jenuh dalam pembelajaran yang menerapkan model pembelajaran yang kurang dinamis. Anak didik sulit berkonsentrasi dalam pelajaran, motivasi belajar kurang, minimnya alat dan sumber belajar untuk kegiatan belajar merupakan problematika pembelajaran umum yang terjadi di tingkat SMP. Dengan pelatihan pembuatan media pembelajaran mandiri dengan model flashcard, meme, comic strip, dan running text diharapkan menjadi solusi dari segala tantangan dan problematika yang dihadapi oleh para guru 
Bahasa Jawa di wilayah Kabupaten Klaten khususnya, dan di wilayah Jawa Tengah, DIY, dan Jawa Timur pada umumnya.

\section{TUJUAN DAN MANFAAT}

Tujuan kegiatan pengabdian yang diikuti oleh para guru-guru yang tergabung dalam MGMP Bahasa Jawa SMP ini adalah untuk: (1) meningkatkan kecakapan dalam bidang teknologi pembelajaran, khususnya dalam pengetikan aksara Jawa atau yang dikenal dengan Hanacaraka dan (2) meningkatkan produktivitas para guru dalam pembuatan media pembelajaran yang bersifat personal, dibuat sendiri dan disesuaikan dengan kebutuhan dan kondisi anak didik melalui flashcard, meme, comic strip, dan running text.

Adapun manfaat yang didapatkan peserta dari mengikuti kegiatan ini antara lain: (1) meningkatkan gairah mengajar dan kualitas proses belajar mengajar di kelas; (2) mempermudah tugas administratif guru dalam membuat perangkat pembelajaran, terutama dalam pembuatan soal latihan, tugas atau pekerjaan rumah, maupun soal ujian; (3) meningkatkan motivasi belajar anak didiknya; (4) ikut berkontribusi melestarikan bahasa Jawa, khususnya melalui aksara Jawa dengan menciptakan media-media pembelajaran adaptif yang senantiasa mengikuti perkembangan zaman.

\section{METODE PELAKSANAAN}

Mitra atau sasaran kegiatan pengabdian ini ialah guru-guru mata pelajaran Bahasa Jawa, khususnya tingkat Sekolah Menengah Pertama yang berada di wilayah Kabupaten Klaten. Jumlah guru bahasa Jawa yang terlibat sebanyak 42 guru yang tergabung dalam Musyawarah Guru Mata Pelajaran Bahasa Jawa SMP se-Klaten, baik berstatus pengurus MGMP maupun sebagai anggota. Guruguru tersebut mewakili sekolah-sekolah yang berada di wilayah Kecamatan Pedan, Trucuk, Bayat, Karangdowo, Cawas, Ngawen, Kebonarum, Wedi, Jatinom, Polanharjo, Tulung, Manisrenggo, Gantiwarno, Kemalang, Prambanan, Delanggu, Ceper, Juwiring, Wonosari, Klaten Utara, Klaten Tengah, dan Klaten Selatan (22 kecamatan dari total 26 kecamatan yang ada di Klaten).

Sebagaimana disebutkan oleh Pawar (2014) bahwa kegiatan pengembangan sumber daya masyarakat tidak hanya terkait dengan usaha penambahan infrastruktur dan fasilitas, peningkatan ekonomi, serta aspek kesehatan dan politik saja. Namun, usaha peningkatan kualitas hidup (dalam konteks ini keterampilan para guru) merupakan bagian penting dalam pemberdayaan masyarakat karena memberikan bekal keterampilan kepada mitra untuk menyelesaikan masalah-masalah yang dihadapinya secara mandiri. Oleh karena itu, kegiatan pengabdian ini didesain dengan aktivitas yang secara umum didominasi menggunakan strategi pelatihan yang berkelanjutan.

Secara runtut, tahapan kegiatan pengabdian ini mulai dari pembentukan tim hingga menentukan kebutuhan dan sasaran baru mengikuti alur kerja sebagaimana yang digambarkan pada diagram alir (Gambar 1) berikut. 


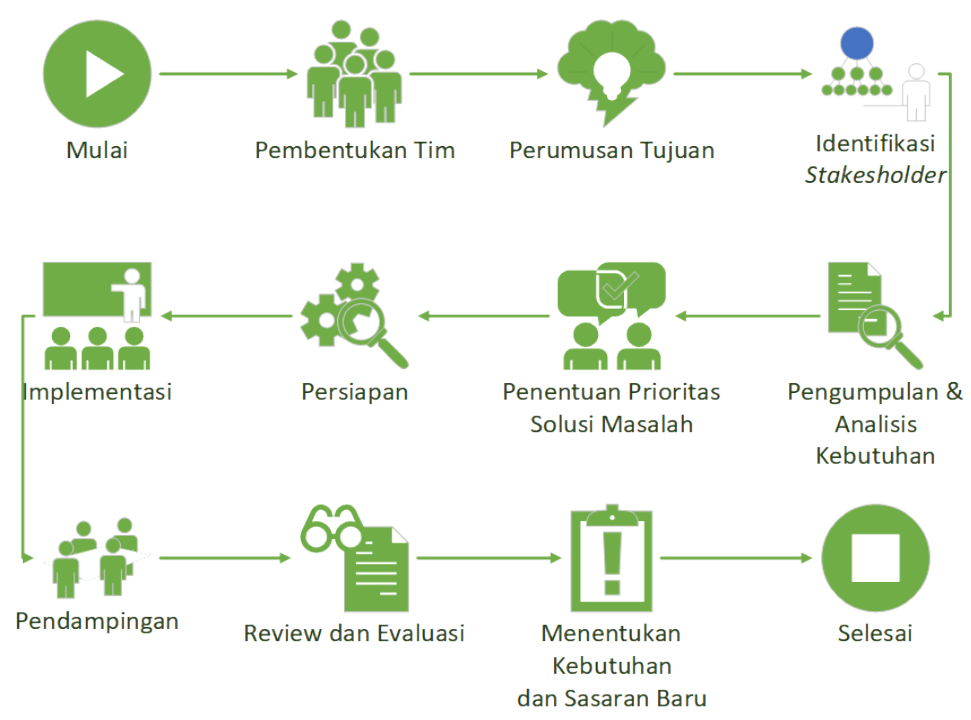

Gambar 1 Alur kerja kegiatan pengabdian kepada masyarakat (diadaptasi dari Vincent II, 20o9)

Kegiatan pengabdian ini diawali dengan pembentukan tim pelaksana yang terdiri dari dosen dan mahasiswa Program Studi Pendidikan Bahasa dan Sastra Daerah, Universitas Widya Dharma dengan latar belakang keilmuwan yang berbeda: pendidikan, bahasa, dan sastra guna menjamin segala kebutuhan prioritas mitra.

Tabel 1 Jadwal Kegiatan Pengabdian

\begin{tabular}{lcl}
\hline \multicolumn{1}{c}{ Kegiatan } & Bulan ke- & \multicolumn{1}{c}{ Metode } \\
\hline Pembentukan tim & $\mathbf{1}$ & FGD \\
Perumusan tujuan & 1 & FGD \\
Identifikasi stakesholder & 1 & FGD \\
Pengumpulan dan analisis kebutuhan & 2 & Wawancara dan survei \\
Penentuan prioritas solusi masalah & 2 & FGD \\
Persiapan & 3 & FGD \\
Implementasi & 4 & Demonstrasi \\
Pendampingan & 5 & Latihan \\
Review dan evaluasi & 6 & Wawancara dan survei \\
Penentuan kebutuhan dan sasaran baru & 6 & FGD \\
\hline
\end{tabular}

Setelah tim pelaksana terbentuk, maka dilakukan FGD (Tabel 1) untuk menentukan dan merumuskan tujuan kegiatan, yakni meningkatkan kualitas SDM pendidik di wilayah Kabupaten Klaten agar mampu menyelesaikan persoalan-persoalan harian terkait tugasnya sebagai guru.

Langkah selanjutnya melakukan identifikasi pemangku kepentingan (stakeholers) terkait, yakni Dinas Pendidikan Kabupaten Klaten. Pengumpulan dan analisis kebutuhan mitra merupakan tahap yang dilakukan berikutnya, menjaring informasi dari para guru dengan mewawancarai beberapa guru dan melakukan survei kebutuhan.

Dari penggalian informasi ini disimpulkan bahwa kendala-kendala yang dihadapi oleh guru Bahasa Jawa antara lain: minimnya media pembelajaran mata pelajaran Bahasa Jawa, kurangnya minat belajar siswa terhadap mata pelajaran Bahasa Jawa, pemahaman mengenai unggah-ungguh basa Jawa yang lemah, kurangnya perbendaharaan kosa kata Jawa anak didik, serta sarana dan prasarana sekolah yang kurang mendukung proses pembelajaran. 


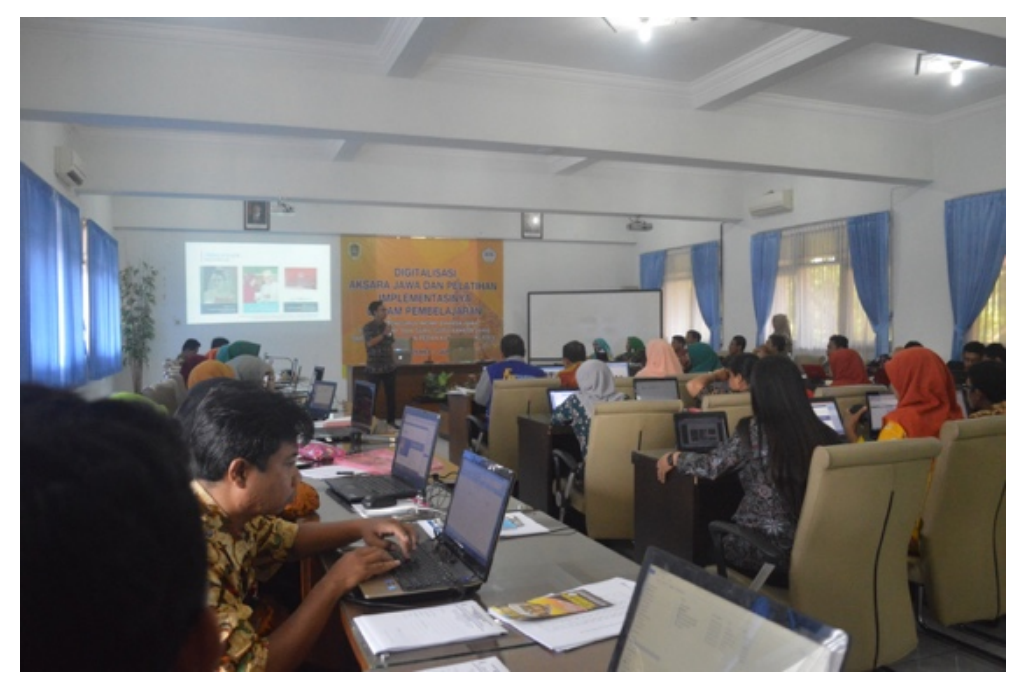

Gambar 2 Suasana pelatihan digitalisasi aksara Jawa

Setelah masalah dipetakan dengan jelas, berikutnya ditentukan prioritas kebutuhan berdasarkan urgensi, luasnya cakupan, dan dampak. Maka, ditentukanlah topik mengenai aksara Jawa karena merupakan faktor kunci dari beberapa kendala pokok yang telah diidentifikasi. Persiapan implementasi kegiatan dilakukan dengan bekerja sama dan berkoordinasi dengan pihak MGMP dan Dinas Pendidikan Klaten mengenai teknis pelaksanaan kegiatan agar berjalan kondusif.

Implementasi kegiatan dilakukan dengan demontrasi pemasangan aksara Jawa di perangkat komputer, mengetik aksara Jawa, dan pembuatan media pembelajaran mandiri (Gambar 3). Setiap materi diikuti dengan latihan-latihan untuk mengasah keterampilan para peserta.

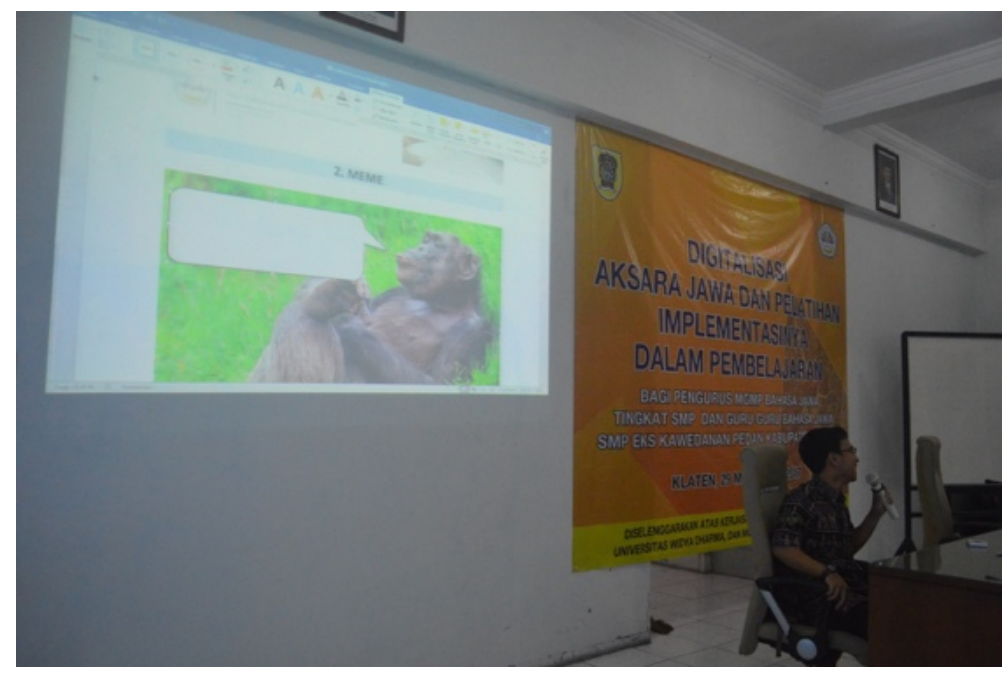

Gambar 3 Fasilitator saat mendemostrasikan pembuatan meme

Setelah kegiatan pelatihan pada tanggal 29 Mei sampai dengan 1 Juni 2017 selesai, peserta diberikan pendampingan untuk menyelesaikan tugas-tugas dalam pembuatan media pembelajaran. Agar lebih efektif dan efisien, pendampingan juga dilakukan dengan non tatap muka dengan memanfaatkan media pesan instan melalui grup WhatsApp.

Review dan evaluasi dilakukan melalui metode wawancara dan survei untuk mengetahui penilaian, kendala yang dihadapi, harapan selanjutnya terkait kegiatan yang sudah terlaksana. Dari hasil evaluasi ini juga ditemukan kebutuhan-kebutuhan dan sasaran baru yang perlu dicarikan solusinya sehingga dapat dilakukan tindak lanjut untuk kegiatan berikutnya. 


\section{HASIL DAN PEMBAHASAN}

Mengingat para peserta setidaknya telah memiliki pengetahuan dan pengalaman yang baik dalam aksara Jawa (dari pelatihan yang telah diselenggarakan sebelumnya), maka agenda pertama yang dilaksanakan adalah melatih melakukan pemasangan fon Hanacaraka pada perangkat komputer masing-masing. Aktivitas ini dilakukan untuk menjamin para peserta agar mampu melakukan pemasangan pada perangkat komputer lainnya. Fon yang dipasang dan dimanfaatkan pada pelatihan ini merupakan fon Hanacaraka karya Teguh Budi Sayugo (Santoso, 2004a, 2004b). Seluruh materi dan modul pelatihan kegiatan ini dapat diakses secara terbuka melalui https://s.id/modulhanacaraka, termasuk panduan pengetikan aksara Jawa yang disusun oleh Santoso (2004a, 2004b).

Setelah pemasangan fon Hanacaraka dapat dipraktikkan dengan baik, peserta kemudian diberikan latihan-latihan terstruktur tentang pengetikan aksara Jawa (Gambar 4) menggunakan perangkat komputer masing-masing (Aribowo, 2017).

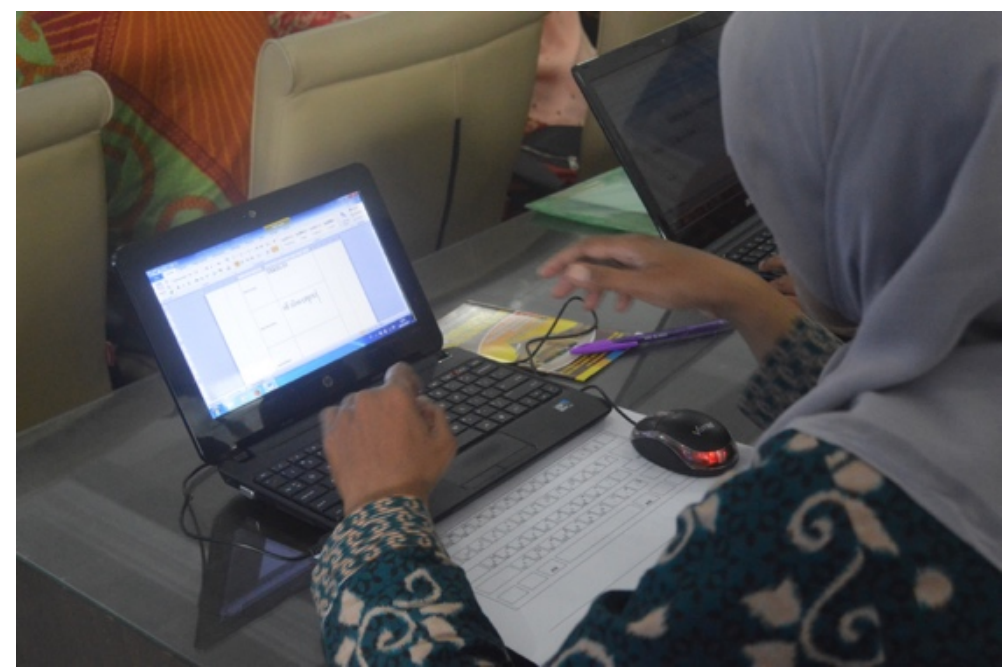

Gambar 4 Salah satu peserta saat mengerjakan latihan mengetik menggunakan aksara Jawa

Tahap pemasangan fon dan pengetikan aksara Jawa menggunakan perangkat komputer dirasa tidak terlalu sulit bagi para peserta. Untuk menampilkan aksara Jawa pada komputer tidak memerlukan papan ketik khusus karena hanya cukup memasang fon Hanacaraka di perangkat komputer. Pengetikan aksara Jawa juga dinilai peserta cukup mudah karena tidak jauh berbeda dengan papan ketik yang lazim tersedia di perangkat komputer, misalnya untuk memunculkan karakter $h a$ menggunakan tuts a; $n a \sim \mathrm{n} ; c a \sim \mathrm{c} ; r a \sim \mathrm{r} ; k a \sim \mathrm{k}$; dan seterusnya, termasuk pasangan.

Latihan diawali dengan penulisan aksara carakan (nglegena), pasangan (mati), tanda baca (sandhangan), penulisan teks Jawa, dan pembuatan soal latihan bagi siswa. Setelah peserta terampil dalam pengetikan aksara Jawa, maka dilanjutkan dengan pembuatan media pembelajaran dengan aksara Jawa melalui flashcard, meme, comic strip, dan running text. Berikut masing-masing proses dan ulasan mengenai pembuatan media pembelajaran dengan memanfaatkan aksara Jawa.

\section{Flashcard Hanacaraka}

Flashcard merupakan media pembelajaran yang lazim digunakan untuk meningkatkan kecerdasan linguistik atau bahasa, terutama terkait pengingkatan perbendaharaan kosa kata (Aribowo, 2014b). Media pembelajaran ini merupakan media yang fleksibel yang dapat digunakan mulai dari tingkat pendidikan dasar hingga perguruan tinggi (Blackwell dan Laman, 1948; Phillips dan Feng, 
2012; Aribowo, 2015b; Rachmita, 2016); bahkan dapat dimanfaatkan untuk anak didik dengan kebutuhan khusus (Erbey et al., 2011; DeLong et al., 2013; Pfaff et al., 2013; LeBrun et al., 2014). Beberapa penelitian menunjukkan bahwa flashcard terbukti merupakan media pembelajaran yang efektif (Erbey et al., 2011; Volpe et al., 2011; Chandra, 2017).

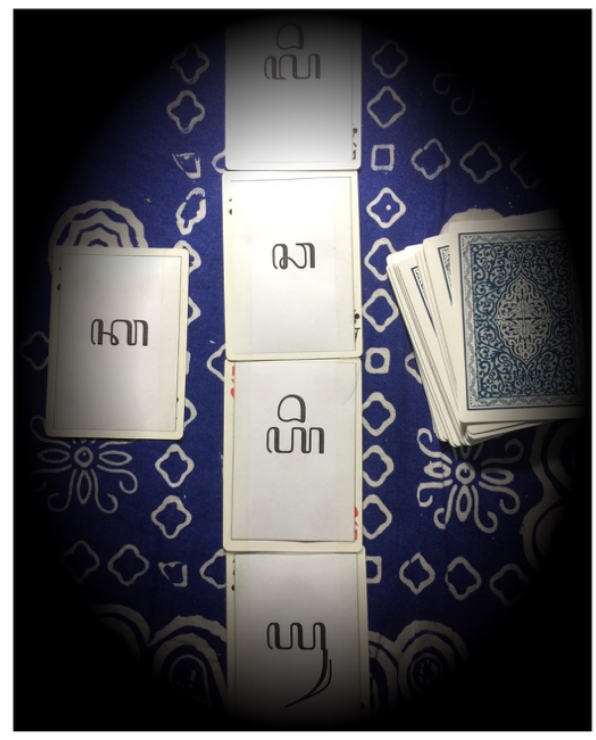

Gambar 5 Contoh flashcard Hanacaraka yang dibuat dengan memodifikasi kartu remi

Langkah-langkah instruksional:

1. Cetaklah keseluruhan aksara Jawa (20 konsonan dan setiap konsonan memiliki variasi 6 vokal, sehinggatotal 120 kartu) pada selembar kertas, abaikan aksara pasangan!

2. Gunting sesuai garis/pola yang ada, kemudian tempel pada kertas karton atau kartu remi!

3. Bagi siswa dalam beberapa kelompok, kemudian bagikan kartu!

4. Layaknya permainan "cangkulan", pemain pertama menjatuhkan kartu sesuka hati, misalnya "KA".

5. Pemain berikutnya harus menyusun kata dari suku kata pertama yang dipilih oleh pemain pertama sesuai dengan kartu yang dimilikinya kemudian mencatatnya dalam selembar kertas, misalnya "LI" menjadi kata "KALI".

6. Pemain ketiga menyusun kata lain dengan masih menggunakan kartu pemain pertama sebagai suku kata pertama (suku kata [KA]), misalnya "KAYU", begitu pula seterusnya hingga pemain terakhir yang tidak mampu melanjutkan menyebut kata PAS.

7. Pemain terakhir yang mampu menyusun kata, memilih kartu sebagai suku kata untuk kata berikutnya, begitu pula seterusnya.

8. Di akhir permainan, jumlah kata yang didapatkan masing-masing pemain direkapitulasi.

9. Apabila terdapat pasangan atau sandhangan lain, pemain wajib menyebutkannya serta menuliskannya di lembar tersebut.

10. Berikan penghargaan pada siswa yang mampu menyusun kata paling banyak!

Setelah mencoba dan mempraktikkan pembuatan flashcard Hanacaraka, sebagian besar peserta berpendapat bahwa media ini merupakan media yang mudah dibuat secara mandiri. Bahkan, kartu dapat diadaptasikan dalam bentuk kata misalnya nama-nama tokoh wayang dan instrumen 
gamelan, tidak hanya kosa kata. Para peserta juga meyakini bahwa flashcard dapat mendukung bertambahnya kosa kata bahasa Jawa yang dikuasai oleh anak didik. Suasana pembelajaran di kelas pun niscaya menjadi hidup karena anak didik belajar sambil bermain (terlibat langsung dalam pembelajaran).

\section{Meme Hanacaraka}

Meme dapat diartikan sebagai gambar yang dimodifikasi dengan penambahan kata-kata singkat untuk tujuan tertentu (Wahyu, 2017). Pada waktu belakangan ini, meme sering kali dimanfaatkan untuk menghibur dan mengkritisi kebijakan tertentu (Listiorini, 2017; Lukmantoro, 2017).

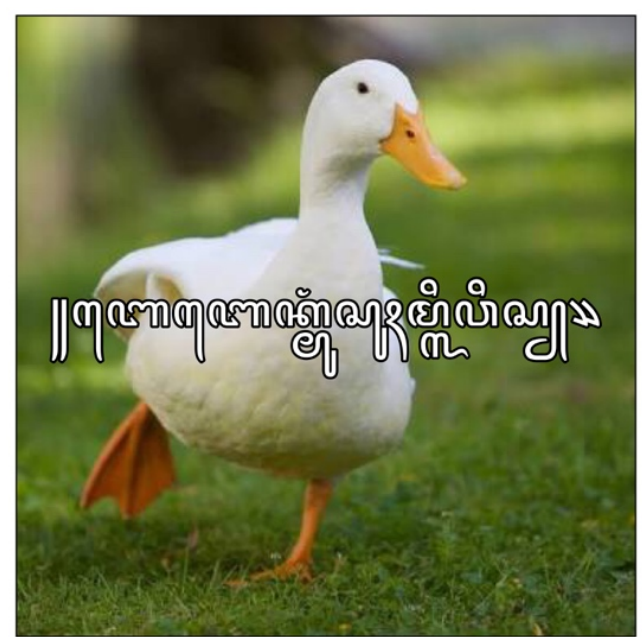

Gambar 6 Salah satu contoh meme yang berasal dari paribasan Jawa

Langkah-langkah instruksional:

1. Carilah beberapa gambar (yang mengandung kesan lucu) melalui mesin pencari atau koleksi pribadi Anda (pilih yang tidak berpotensi menyinggung unsur SARA, pornografi, kekerasan, dan politik)!

2. Mintalah siswa untuk menyusun/melanjutkan sebuah parikan, cangkriman, paribasan, sesanti atau kata-kata lain sesuai dengan konteks gambar tersebut!

3. Ajaklah siswa berdiskusi untuk menentukan tiga (atau lima) kata-kata favorit pada meme tersebut!

4. Tempel meme-meme favorit tersebut di papan tulis!

5. Siapkan kertas kecil untuk pemilihan suara!

6. Minta siswa maju satu per satu untuk memberikan suaranya.

7. Hitung perolehan suara secara bersama dan transparan (terbuka layaknya pemilu atau pilkada)!

8. Berikan penghargaan bagi siswa yang mendapatkan poin terbanyak!

Menurut para peserta, media pembelajaran dalam bentuk meme ini dapat dikreasikan dengan menambahkan teks nasihat yang berasal dari macapat, tembang dolanan, atau cangkriman yang lucu. Meme ini juga dapat disebarluaskan melalui pesan instan atau media sosial sehingga masyarakat, khususnya anak didik sering dan terbiasa menghadapi gambar yang bertuliskan aksara Jawa. Meme ini sebenarnya juga dapat dibuat secara langsung melalui smartphone apabila telah mendukung pengetikan aksara Jawa. 


\section{Comic Strip}

Media pembelajaran berupa comic strip juga banyak dikenal di kalangan pendidik sebagai salah satu media yang efektif dalam pembelajaran bahasa, terutama untuk meningkatkan kompetensi menulis anak didik (Budiman, Mahdum dan Burhan, 2011; Rokhayani dan Utari, 2014; Hamidah, Usman dan Muhsin, 2015; Humola dan Talib, 2015).

Comic strip merupakan rangkaian gambar yang disajikan secara singkat dan berseri dan biasanya dimuat di majalah atau surat kabar (Soedarso, 2015). Comic strip merupakan media yang atraktif dan dapat diterapkan dalam pembelajaran karena sifatnya yang tidak mengenal kelompok usia maupun tingkatan sosial (Budiman, Mahdum dan Burhan, 2011; Rokhayani dan Utari, 2014). Penerapa media pembelajaran ini di kelas dapat membuat anak didik termotivasi, pembelajaran menjadi menyenangkan, dapat mengeksplorasi ide-ide anak didik (Hamidah, Usman dan Muhsin, 2015), serta meningkatkan partisipasi dan keterlibatan siswa dalam pembelajaran (Humola dan Talib, 2015).

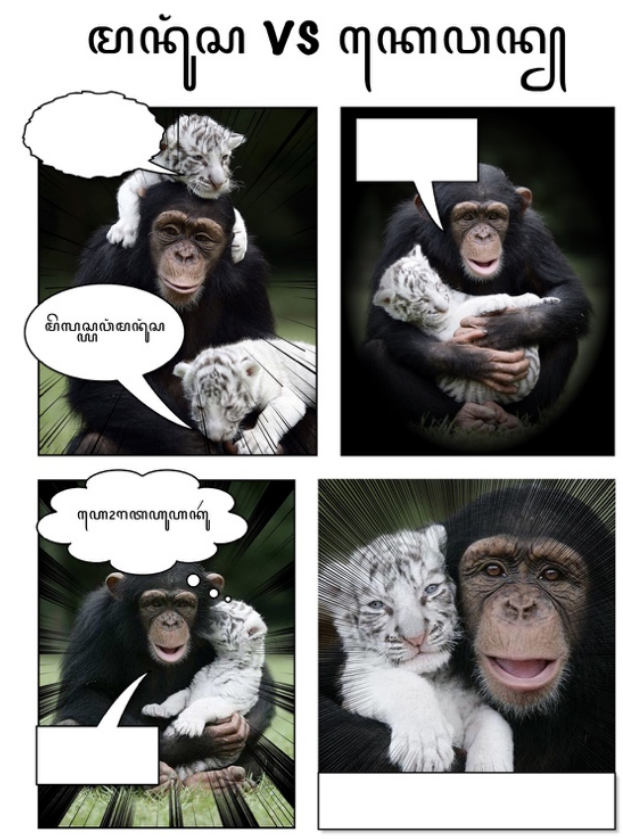

Gambar 7 Salah satu comic-strip yang ditulis dengan aksara Jawa

Langkah-langkah instruksional:

1. Carilah beberapa gambar melalui mesin pencari atau koleksi pribadi Anda (pilih yang tidak berpotensi menyinggung unsur SARA, pornografi, kekerasan, dan politik)!

2. Pilihlah gambar-gambar yang mudah untuk dibuat skenario!

3. Buatlah beberapa alternatif skenario awal dari gambar-gambar tersebut!

4. Buatlah beberapa teks percakapan sebagai stimulan untuk siswa agar dapat meneruskan cerita dengan skenarionya masing-masing!

5. Bagi siswa ke dalam beberapa kelompok lalu mintalah mereka untuk mengisi balon percakapan yang telah disediakan sehingga membentuk sebuah cerita yang runtut!

6. Dari teks percakapan tersebut, masing-masing kelompok membuat cerita yang lengkap dengan skenario yang telah didiskusikan. 
7. Masing-masing kelompok menceritakan dan melaporkan kontribusi anggotanya dalam penyusunan cerita tersebut.

8. Berikan penghargaan bagi kelompok dengan penulisan cerita terbaik!

Menurut pengamatan dan beberapa komentar dari peserta, pembuatan media pembelajaran dengan model comic strip merupakan media yang paling sukar untuk dibuat apabila dibandingkan dengan model-model lainnya. Hal ini disebabkan karena peserta merasa sulit untuk menemukan rangkaian gambar yang bersifat kronologis, yang menceritakan sebuah kejadian secara runtut. Solusi untuk kendala ini, para peserta dapat menggunakan foto atau gambar koleksi pribadi yang diambil menggunakan kamera digital atau smartphone yang menceritakan tentang kearifan lokal misalnya legenda atau mitos yang hidup di masyarakat, perilaku atau tindakan sehari-hari yang mencerminkan kepribadian masyarakat Jawa, atau pengalaman pribadi guru. Cerita juga dapat diambil dari dongeng, fabel, cerkak, cerita inspiratif yang dimuat di koran atau majalah. Guru juga dapat melibatkan anak didik dalam pencarian ide cerita dan gambar pendukung.

\section{Running Text}

Running text merupakan informasi singkat yang disisipkan pada acara-acara televisi yang ditayangkan berupa teks yang berjalan di bawah layar untuk berita-berita penting yang sedang terjadi (Verawati, Wibisono dan Rochiyati, 2014). Layanan ini berfungsi untuk mempermudah pemirsa televisi dalam mengkonsumsi berita hangat yang sedang terjadi tanpa harus menyaksikan keseluruhan konten liputan berita. Meskipun belum pernah diterapkan dalam pembelajaran, namun adaptasi running text sebagai media pembelajaran diyakini dapat mendukung keterampilan menulis dan membaca anak didik.

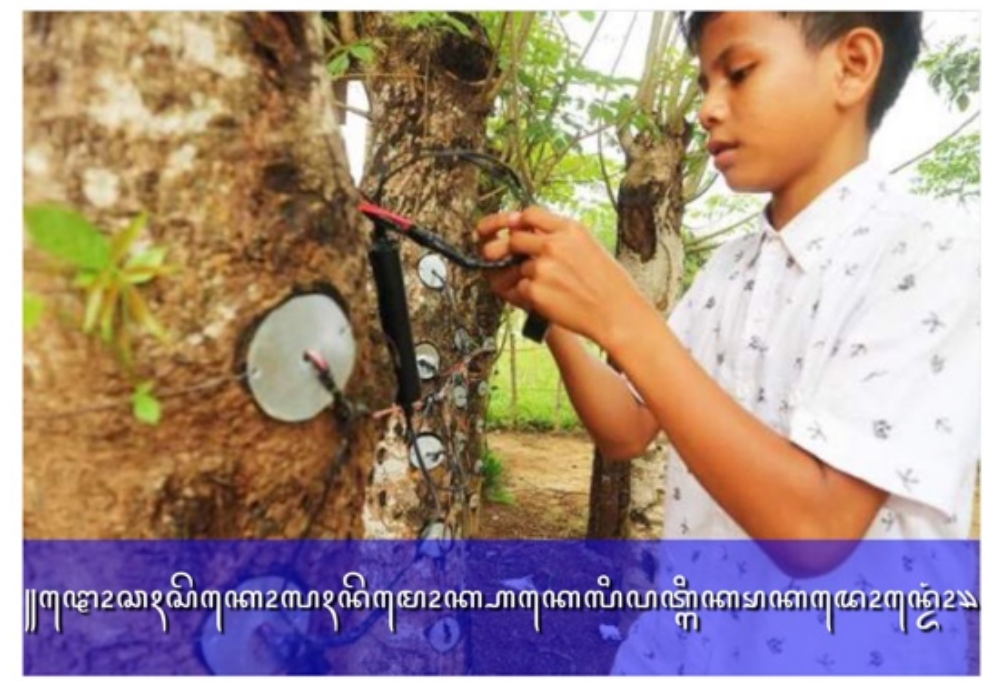

Gambar 8 Salah satu contoh running text berita tentang Nauval, siswa SMP yang menciptakan listrik dari pohon kedondong

Langkah-langkah instruksional:

1. Baca dan kutiplah sebuah berita aktual yang dimuat di media massa terpercaya! Pilih berita yang ringan untuk usia remaja!

2. Cari gambar melalui mesin pencari yang melukiskan berita tersebut!

3. Alih-bahasakan ke dalam bahasa Jawa!

4. Susunlah informasi berita tersebut ke dalam sebuah kalimat yang jelas (tajuk utama berita)! 
5. Tuliskan pada gambar dan adopsikan layaknya running text dengan menggunakan aksara Jawa!

6. Bagilah siswa dalam kelompok (dua-dua) kemudian mintalah untuk berdiskusi mengenai informasi dari running text tersebut!

7. Mintalah siswa untuk menulis informasi yang diketahuinya terkait berita tersebut ke dalam sebuah narasi pendek dengan bahasanya masing-masing!

8. Tukarkan hasil kerja mereka dengan kelompok lain!

9. Mintalah masing-masing kelompok untuk membacakan hasil karangan tersebut layaknya seorang pembaca berita di sebuah stasiun televisi atau penyiar radio!

10. Berikan penghargaan untuk penyaji terbaik!

Beberapa model running text yang dibuat para peserta memuat konten berita yang kurang sesuai untuk konsumsi anak didik karena mengandung isu-isu yang mengandung SARA. Konten berita sebisa mungkin disesuaikan dengan usia dan karakteristik anak didik serta dipilih tema-tema yang disukai remaja saat ini. Guru juga disarankan mendengarkan radio atau TV Edukasi untuk memperoleh informasi dan berita aktual yang terjadi. Tren kuliner dan pariwisata yang belakangan menjadi isu hangat juga dapat dijadikan materi untuk media pembelajaran running text.

Selepas pelatihan dan kegiatan pendampingan selesai, keseluruhan proses kegiatan kemudian dievaluasi secara bersamaan bersama mitra. Evaluasi dilakukan dengan wawancara dan survei yang diakses secara daring oleh para peserta melalui https://s.id/evaluasihanacaraka.

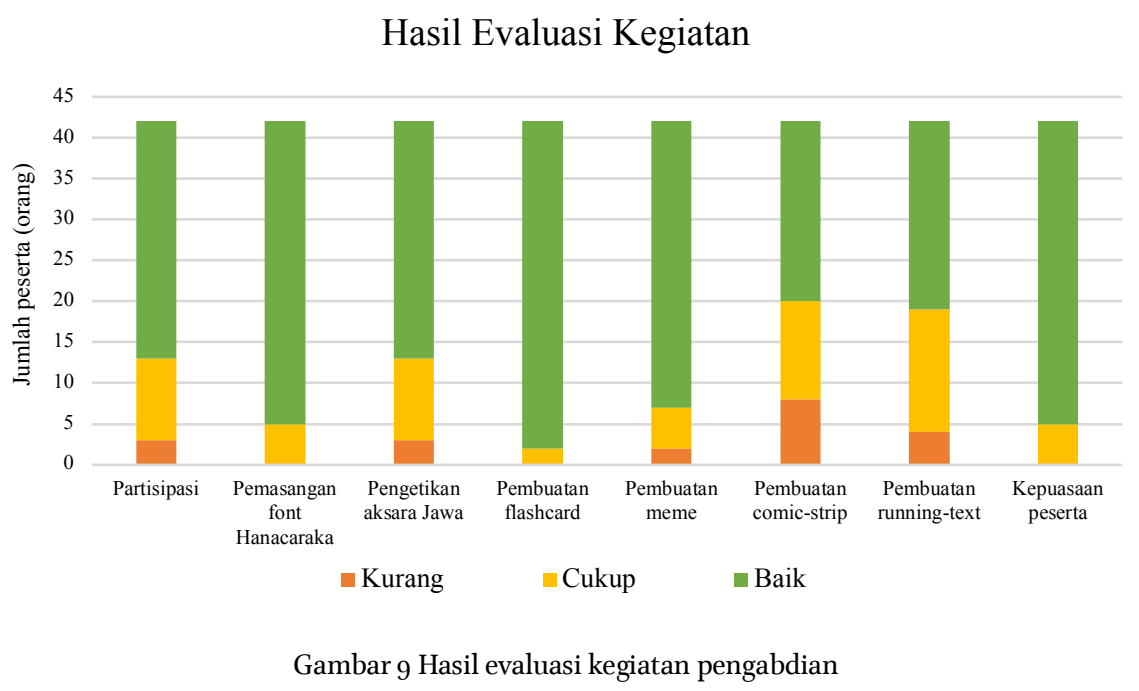

Evaluasi yang ditelusuri melalui wawancara dan survei menunjukan bahwa secara berturutturut media pembelajaran yang mudah dipraktikkan adalah flashcard, meme, running text, dan comic strip. Meskipun comic strip dianggap sebagai media pembelajaran yang paling sukar untuk dibuat, namun pada praktiknya seluruh peserta mampu membuat comic strip dengan cerita yang beragam dan menarik.

Dari hasil evaluasi juga menunjukkan bahwa 40 peserta $(95,24 \%)$ berpendapat dan berencana akan menerapkan media-media pembelajaran yang telah dibuat di kelas masing-masing. Para peserta optimis karena media pembelajaran ini diyakini lebih aplikatif dan apabila diterapkan dalam proses belajar mengajar di kelas, maka suasana pembelajaran akan lebih hidup dan lebih menarik perhatian siswa sehingga pembelajaran Bahasa Jawa dapat menjadi mata pelajaran yang lebih diminati anak didik. Sebagian kecil peserta merasa ragu untuk menerapkannya di kelas dengan alasan 
sarana dan prasarana sekolah yang kurang memadai, misalnya terkait koneksi internet untuk menelusuri bahan-bahan dan sumber belajar.

\section{SIMPULAN DAN SARAN}

Secara garis besar dapat dikatakan kegiatan pengabdian ini sukses meskipun diikuti oleh peserta dengan latar belakang usia yang beragam. Tingginya antusiasme peserta tidak hanya ditunjukkan pada saat pelatihan dan pendampingan berlangsung. Namun, minat dan antusiame peserta juga diwujudkan dengan besarnya harapan agar kegiatan peningkatan kompetensi guru sejenis dapat diselenggarakan secara periodik dan dalam waktu yang tidak terlalu lama.

Diharapkan setelah kegiatan ini berlangsung, para peserta segera mengaplikasikan media-media pembelajaran yang telah dibuat ke dalam proses belajar mengajar di kelas masing-masing. Selain itu, diharapkan media-media pembelajaran yang sudah dibuat dapat dimodifikasi dan dieksplorasi lebih lanjut, tidak hanya terbatas pada media pembelajaran yang telah diajarkan dengan berbekal kemampuan mengetik menggunakan aksara Jawa. Para peserta yang terlibat dalam pelatihan ini juga diharapkan dengan segera melatih guru-guru Bahasa Jawa lain, baik di sekolah masingmasing maupun melalui fasilitasi oleh MGMP.

Kendala-kendala lain yang banyak ditemukan pada proses pembelajaran mata pelajaran Bahasa Jawa di antaranya: unggah-ungguh basa Jawa kerap dianggap sebagai materi yang sukar untuk dipelajari siswa, tembang macapat, minimnya perbendaharaan kosa kata bahasa Jawa pada anak didik, serta sarana dan prasarana pembelajaran lainnya. Penerapan smartphone sebagai media pembelajaran juga menjadi perhatian dan ketertarikan khusus para peserta untuk agenda berikutnya.

\section{UCAPAN TERIMA KASIH}

Keberhasilan dan kesuksesan pelaksanaan kegiatan pengabdian kepada masyarakat ini tidak lepas dari bantuan berbagai pihak. Oleh karena itu, pada kesempatan ini penulis mengucapkan terima kasih kepada pihak-pihak terkait antara lain: (1) Pantoro, selaku Kepala Dinas Pendidikan Kabupaten Klaten; (2) Ngadi, Ketua MGMP Bahasa Jawa SMP Kabupaten Klaten; dan (3) LPPM Universitas Widya Dharma atas bantuan dana yang diberikan; dan (4) Krisna Pebryawan, Luwiyanto, dan para mahasiswa PBSD yang terlibat sebagai tim pelaksana pengabdian. Tidak lupa pula penulis ucapkan terima kasih kepada para reviewer yang telah memberikan komentar konstruktif dalam penulisan artikel ini; dan (5) rekan sejawat yang telah memberikan komentar awal tulisan ini.

\section{DAFTAR PUSTAKA}

Aribowo, E. K. (2014a) "iPadagogi dalam Praktik: Sebuah Model m-learning dalam Pembelajaran Bahasa," in Xiaoqiang, Y., Jackson, N., Rahayu, T., Woodrich, C. A., Sudaryani, R. R. S., Purwanto, W. E., dan Wulandari, Y. (ed.) Seminar Internasional dalam rangka PIBSI XXXVI 2014. Yogyakarta, ID: PBSI UAD, hal. 327-335.

Aribowo, E. K. (2014b) "Media Pembelajaran DIY: Membuat Flash Card dan Teka-Teki Silang Mandiri," in Pembelajaran Bahasa untuk Meningkatkan Kualitas Manusia Indonesia yang Berkarakter dalam Era Mondial. Klaten, hal. 140-150. Tersedia pada: http://journal.unwidha.ac.id/index.php/proceeding/article/view/5o8/446

Aribowo, E. K. (2015a) "Pemanfaatan Smartphone Semaksimal Mungkin: Digitalisasi Produk 
Kebahasaan ke dalam Aplikasi sebagai Solusi Mitigasi Pergeseran Bahasa Jawa," Magistra, 26(91), hal. 21-28. Tersedia pada: http://journal.unwidha.id/index.php/magistra/article/download/575/462

Aribowo, E. K. (2015b) "Quizlet: Penggunaan Aplikasi Smartphone untuk Siswa dalam Mendukung Mobile Learning," in Seminar Nasional Pendidikan Bahasa Indonesia. Surakarta, hal. 31-38. Tersedia pada: https://publikasiilmiah.ums.ac.id/bitstream/handle/11617/6379/Eric Kunto Aribowo.pdf

Aribowo, E. K. (2017) "Lembar Latihan Peserta." Open Science Framework. doi: $10.17605 / O S F . I O / Q W B R S$.

Blackwell, R. dan Laman, S. (1948) "Strategies to Teach Sight Words in an Elementary Classroom," International Journal of Education ISSN, 5(4). doi: 10.5296/ije.v5i4.4024.

Budiman, Mahdum dan Burhan, W. (2011) "Increasing The Ability of SMAN 12 Pekanbaru Students in Writing an Analytical Exposition Text through Comic Strips," Nuances, 3(1), hal. 36-44.

Chandra, R. D. A. (2017) "Pengembangan Media Visual Kartu Angka Efektif untuk Mengenalkan Huruf Vokal a, i, u, e, o pada Anak Usia Dini 3-4 Tahun PAUD Labschool Jember," INDRIA:Jurnal Ilmiah Pendidikan Prasekolah dan Sekolah Awal, 2(1), hal. 45-71. doi: 10.24269/jin.v2n1.2017.pp62-71.

DeLong, L., Mclaughlin, T. F., Neyman, J. dan Wolf, M. (2013) "The Effects of Direct Instruction Flashcard System and Model, Lead, and Test on Numeral Identification for a Nonverbal Preschool Girl with Developmental Delays," Asia Pacific Journal of Multidisciplinary Research, 1(1), hal. 1-11.

Erbey, R., McLaughlin, T. F., Derby, K. M. dan Everson, M. (2011) “The effects of using flashcards with reading racetrack to teach letter sounds, sight words, and math facts to elementary students with learning disabilities," International Electronic Journal of Elementary Education, 3(3), hal. 213-226. Tersedia pada: https://iejee.com/index.php/IEJEE/article/view/228

Gubernur Jawa Tengah (2012) Peraturan Daerah Provinsi Jawa Tengah Nomor 9 Tahun 2012 tentang Bahasa, Sastra, dan Aksara Jawa. Indonesia. Tersedia pada: http://jdihukum.jatengprov.go.id/download/produk_hukum/perda/perda_tahun_2012/perda_ 9_th_2012.pdf.

Gubernur Jawa Tengah (2013) Petunjuk Pelaksanaan Peraturan Daerah ProvinsiJawa Tengah Nomor 9 Tahun 12 tentang Bahasa, Sastra, dan Aksara Jawa. Indonesia: Peraturan Gubernur Jawa Tengah. Tersedia pada: http://jdihukum.jatengprov.go.id/download/produk_hukum/pergub/pergub_tahun_2013/perg ub_57_th_2013.pdf.

Hamidah, N., Usman, S. dan Muhsin (2015) "Improving Writing Skill of The Eight Graders through Comic Strip," Journal of English Language Teaching Society (ELTS), 3(2), hal. 1-11.

Humola, Y. dan Talib, R. (2015) "Enhancing The Students Writing Ability by Using Comic Strip: An 
action research conducted at the tenth grade of SMA Negeri I Tapa," in ICTTE FKIP UNS 2015, hal. 614-623.

Kartikasari, D. dan Nugroho, G. K. (2010) "Media Pembelajaran Interaktif Mata Pelajaran Bahasa Jawa Pokok Bahasan Aksara Jawa pada Sekolah Menengah Pertama Negeri 2 Tawangsari Kabupaten Sukoharjo," Journal SPEED: Sentra Penelitian Engineering dan Edukasi, 2(3), hal. 1-6.

LeBrun, C., Jones, S., Neyman, J., Mclaughlin, T. F. dan Schuler, H. (2014) "The Effects of a Modified Direct Instruction Flashcard System on a 14 Year-Old-Student with Learning Behavioral Issues Enrolled in a Behavior Intervention Classroom," International Journal of Undergraduate Research and Creative Activities, 6(4), hal. 1-9. doi: 10.7710/2168-0620.1033.

Listiorini, A. (2017) "Wacana Humor dalam Meme di Media Online sebagai Potret Kehidupan Sebagian Masyarakat Indonesia," LITERA, 16(1), hal. 64-77. Tersedia pada: https://journal.uny.ac.id/index.php/litera/article/view/14251/pdf

Lukmantoro, T. (2017) "Menertawakan Fobia Komunis di Era Reproduksi Digital," Profetik: Jurnal Komunikasi, $10(1)$ hal. $5^{0-71}$ Tersedia pada: http://ejournal.uinsuka.ac.id/isoshum/profetik/article/view/1221/11o9

Pawar, M. (2014) Social and Community Development Practice. New Delhi: SAGE Publications.

Pfaff, E., Mclaughlin, T. F., Neyman, J. dan Everson, M. (2013) “The Effects of Direct Instruction Flashcards with Math Racetrack with Addition Facts for an Elementary School Student with ADHD," International Journal of Basic and Applied Science, 2(1), hal. 124-130. Tersedia pada: https://www.insikapub.com/Vol-o2/No-01/11JBAS(2)(1).pdf

Phillips, W. E. dan Feng, J. (2012) "Methods for Sight Word Recognition in Kindergarten: Traditional Flashcard Method vs. Multisensory Approach," in Annual Conference of Georgia Educational Research Association, hal. 1-37. Tersedia pada: https://files.eric.ed.gov/fulltext/ED536732.pdf

Rachmita, N. M. (2016) "Vocabulary Development of Kindergarten Students of Apple Tree PreSchool Samarinda by Using Flashcard," Script Journal:Journal of Linguistic and English Teaching, 1(2), hal. 119-13o. doi: 10.24903/sj.vii2.27.

Rokhayani, A. dan Utari, A. R. P. (2014) "The Use of Comic Strips as an English Teaching Media for Junior High School Students," Language Circle:Journal of Language and Literature, VIII(2), hal. $143^{-149 .}$

Santoso, T. B. (2004a) Dokumentasi dan Panduan Pemakaian Hanacaraka Trutype Font untuk Perangkat Lunak Komputer Berbasis Sistem Operasi Windows. Purwokerto.

Santoso, T. B. (2004b) Panduan Pemakaian Hanacaraka Font untuk Pengetikan Aksara Jawa pada Perangkat Lunak Komputer Berbasis Sistem Operasi Windows. Purwokerto.

Soedarso, N. (2015) “Komik: Karya Sastra Bergambar," Humaniora, 6(4), hal. 496-5o6. Tersedia pada: http://journal.binus.ac.id/index.php/Humaniora/article/view/3378/2757 
Verawati, E., Wibisono, B. dan Rochiyati, A. E. (2014) "Ciri-Ciri Bahasa Running Text pada Kabar Pagi di Channel TVOne," Publika Budaya, 3(2), hal. 41-51.

Vincent II, J. W. (Jack) (2009) "Community development practice," in Rhonda, P. dan Pittman, R. H. (ed.) An Introduction to Community Development. New York: Routledge, hal. $5^{8-74 .}$

Volpe, R. J., Mule, C. M., Briesch, A. M., Joseph, Laurice, M. dan Burns, M. K. (2011) “A Comparison of Two Flashcard Drill Methods Targeting Word Recognition," Journal of Beharior Education, 20, hal. 117-137.

Wahyu, D. (2017) "Kata 'Hoaks' dan 'Meme' Sudah Tercatat di Kamus Bahasa Indonesia," Kompas.com, 28 Februari. Tersedia pada: http://nasional.kompas.com/read/2017/o2/28/13203281/kata.hoaks.dan.meme.sudah.tercatat.d i.kamus.bahasa.indonesia. 